\title{
Landfill Siting Using GIS and AHP (Analytical Hierarchy Process): A Case Study Al-Qasim Qadhaa, Babylon, Iraq
}

\author{
Ali Jalil Chabuk ${ }^{1}$, Nadhir Al-Ansari ${ }^{1}$, Hussain Musa Hussain ${ }^{2}$, Sven Knutsson ${ }^{1}$ and Roland Pusch $^{1}$ \\ 1. Department of Civil Environmental and Natural Resources Engineering, Lulea University of Technology, Lulea 971 87, Sweden \\ 2. Department of Geology, Faculty of Science, University of Kufa, Kufa 16008, Iraq
}

\begin{abstract}
The selection of a landfill site is considered as a complicated task because this process is based on many factors and restrictions. For Al-Qasim Qadhaa, which is situated in the southern part of the Babylon Governorate, Iraq, there is no landfill site in that area that conforms to the scientific criteria for selecting sites for landfill. For this reason, 15 criteria were adopted in this study (groundwater depth, rivers, soil types, agriculture lands use, land use, elevation, slope, gas pipelines, oil pipelines, power lines, roads, railways, urban centers, villages and archaeological sites) using GIS (geographic information system), which has a large ability to manage input data. In addition, the AHP (analytical hierarchy process) method was used to derive the relative weightings for each criterion using pair-wise comparison. To obtain the suitability index for candidate landfill sites, a weighted linear combination method was used. After combining these methods, two suitable candidate landfill sites, with areas of $2.766 \mathrm{~km}^{2}$ and $2.055 \mathrm{~km}^{2}$, respectively, were found to satisfy the scientific and environmental requirements. The area of these sites can accommodate solid waste from 2020 until 2030 based on the required area, which was $0.702 \mathrm{~km}^{2}$.
\end{abstract}

Key words: Landfill, Al-Qasim Qadhaa, AHP (analytical hierarchy process), GIS, WLC (weighted linear combination).

\section{Introduction}

In developing countries, solid waste management is considered one of the important issues related to environmental management and, through proper management of solid waste, pollution and the health risks which arise in open dumping sites that are often commonly used for the disposal of this waste can be avoided [1]. MSW (management of solid waste) consists of many processes, including recycling, reducing the waste, recovery of energy, incineration of the waste, and landfill [2]. A sanitary landfill is necessary to a waste management system even if other techniques of waste management are adopted. In countries that burn or recycle large parts of their waste, the remains of these processes still need a suitable landfill site because landfill is simple to use and relatively cheap [3-5]. Within the last two decades, researchers have exerted great efforts in satisfying

Corresponding author: Nadhir Al-Ansari, professor, research fields: water and environmental engineering. different aspects of landfill management, particularly selecting a suitable site for landfill [6, 7]. The process of site selection is considered to be one of the most difficult tasks related to solid waste management systems and a major concern for planners and authorities. This is because this process is subject to factors such as government regulation, government and municipal funding, urbanization, increasing population densities, growing environmental awareness, public environmental health, reduced land availability for landfills and increasing political and social opposition to the establishment of landfill sites $[8,9]$.

GIS (geographic information system) and a spatial multi-criteria decision analysis should be used in landfill siting because they are powerful, integrated tools used to solve the problem of landfill site selection. Decision makers often use MCDA (multi criteria decision analysis) to handle large quantities of complex information. GIS has a significant role in contributing to the selection a landfill site. There are many advantages of applying GIS in the process of landfill 
siting. It reduces time and cost in the siting process, and it has a high ability to manage large volumes of spatial data from variety of sources. GIS may also be used for identifying routes for transporting waste to transfer stations and then to a landfill site and vice versa [2, 1011$]$. AHP (analytical hierarchy process) is a multi-criteria decision-making approach that was developed by Saaty [12] in 1980 to standardize these multi-criteria in the process of making decisions. The mathematical properties of AHP have attracted the attention of many researchers because the required input data are easy to obtain. This process can be used to solve complex multi-criteria decision-making problems. It uses a multi-level hierarchical structure to determine the weighted percent of the multi-criteria [13]. AHP is used to determine the most suitable landfill site among many candidate sites. The relevant data are utilized to obtain relative weightings using pair-wise comparisons of decision criteria in a matrix of the problem $[2,14,15]$.

In the literature [7, 16-18], several potential landfill sites have been identified among many candidate sites using GIS and AHP.

This study seeks to identify a suitable candidate site for landfill through using the AHP, weighted linear combination method and GIS in Al-Qasim Qadhaa in the Babylon Governorate, Iraq.

\section{Methodology}

\subsection{Study Area}

Al-Qasim Qadhaa is considered one of the major cities of the newly formed Babylon Governorate, Iraq. Until recently, the cities of this Qadhaa (Al-Qasim and Al-Talyaah) were administratively controlled by Al-Hashimiyah Qadhaa, which is located in the southern part of the Babylon Governorate, between Al-Hillah Qadhaa and Al-Hashimiyah Qadhaa (Fig. 1).

Al-Qasim Qadhaa has an area of $637 \mathrm{~km}^{2}$, which constitutes $17.1 \%$ of the total area of the Babylon Governorate [19]. It is situated between longitude $44^{\circ} 27^{\prime} 41^{\prime \prime} \mathrm{E}$ and $44^{\circ} 49^{\prime} 24^{\prime \prime} \mathrm{E}$, and latitude $32^{\circ} 25^{\prime} 53^{\prime \prime} \mathrm{N}$ and $32^{\circ} 5^{\prime} 53^{\prime \prime}$ N (Fig. 1).

The official population of Al-Qasim Qadhaa was 184,605 inhabitants in 2015 [20], which equates to $8.8 \%$ of the total population of the Babylon Governorate. Around 146,465 (79.33\%) of the inhabitants live in urban regions, and 38,139 (20.67\%) of the inhabitants live in rural regions.

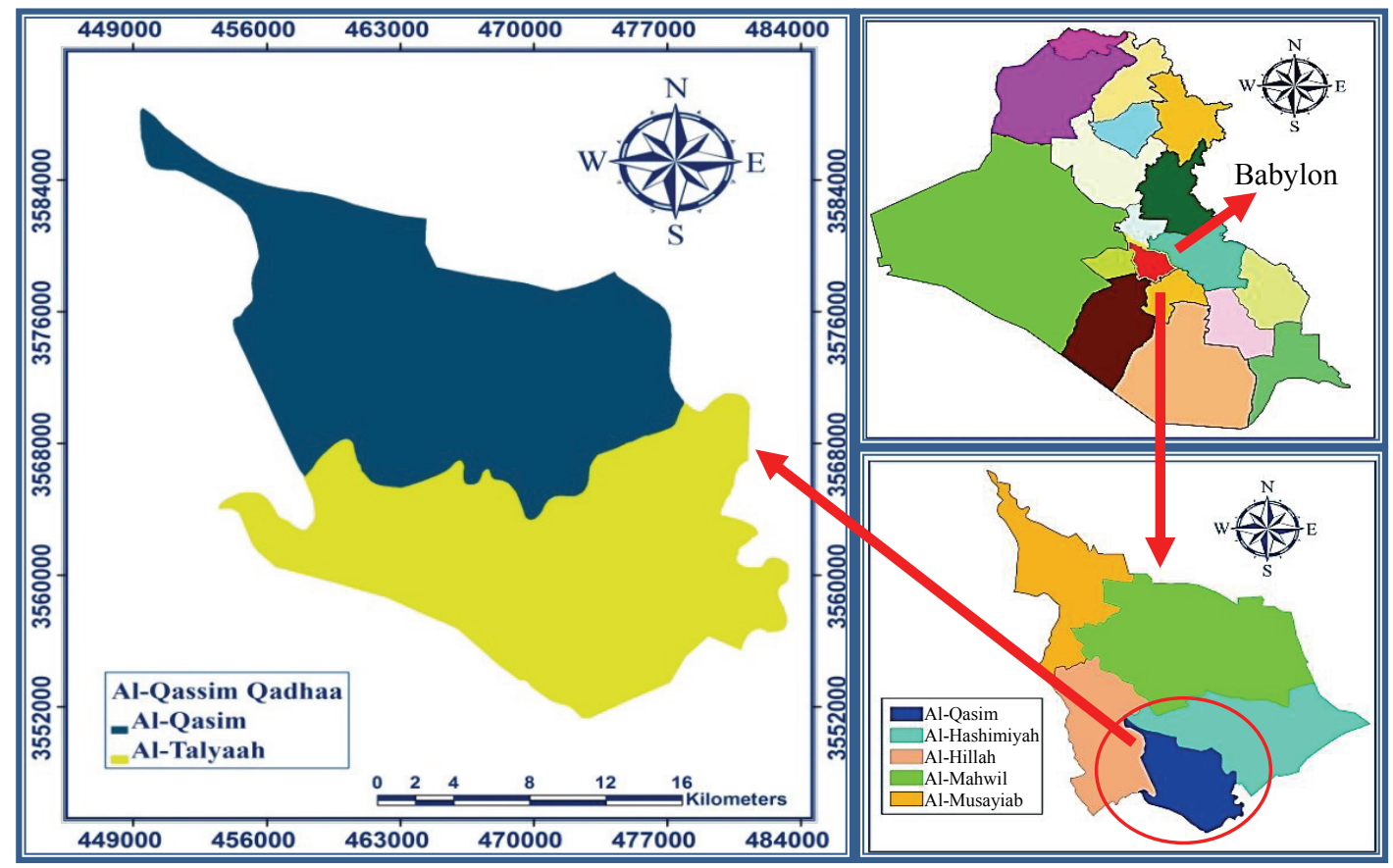

Fig. 1 The study area across Al-Qasim Qadhaa, Babylon Governorate, Iraq. 


\subsection{Decision-Making Tree for Landfill Siting}

The selection of a suitable landfill site considers the main aim of the decision hierarchy. The hierarchical structure of the decision problem includes three levels. The first level has been classified into two categories: natural environmental factors and artificial factors. The second level is comprised of six categories of the criteria: hydrological, land, topographical, infrastructure, accessibility and social-cultural. The third level included 15 criteria used to establish suitable candidate sites for landfill in this study. These criteria are groundwater depth, rivers, soil types, agriculture lands use, land use, elevation, slope, gas pipelines, oil pipelines, power lines, roads, railways, urban centers, villages and archaeological sites (Fig. 2).

\subsection{Preparing Layers Maps of Criteria}

After selecting the important criteria that are related to the present study, the required maps were obtained to prepare the digitized criteria map layers. Some of these maps were digital as a shape file (vector), while the remaining maps need to be converted to be digital maps as a shape file. The individual shape file maps for topography, slope, river, road, urban centers, villages, gas pipelines, oil pipelines, power lines and railways were prepared accordingly using the internal reports of the Iraqi Ministry of Education. The readings of 170 wells for the depths of groundwater were entered into GIS to generate an interpolation between them using the spatial extension tool called Kriging in order to produce the shape file of groundwater depths [21]. For creating the shape file of "soil types", the map of exploratory soil of Iraq (scale 1:1,000,000) [22] was used. The shape file of "agricultural land" was obtained using the land capability map of Iraq (scale 1:1,000,000) and was checked by analyzing satellite images of the Babylon Governorate from 2011 [23]. The archaeological map of Iraq (2013) [24] indicates the locations of archeological and religious sites in this Qadhaa. The map of industrial areas (scale 1:400,000) [19] shows industrial areas within this Qadhaa. These maps were prepared within GIS using its spatial analysis tools as a separate shape file using the relevant information in each map, and then they were converted to the raster maps. All information was projected onto WGS (world geodetic system) 1984 using a projected coordinate system [25].

\subsection{Restriction of Locations Using Buffer Zone}

Identifying the most suitable site for landfill needs a process of large-scale evaluation. Any chosen site should satisfy the governmental regulations requirements

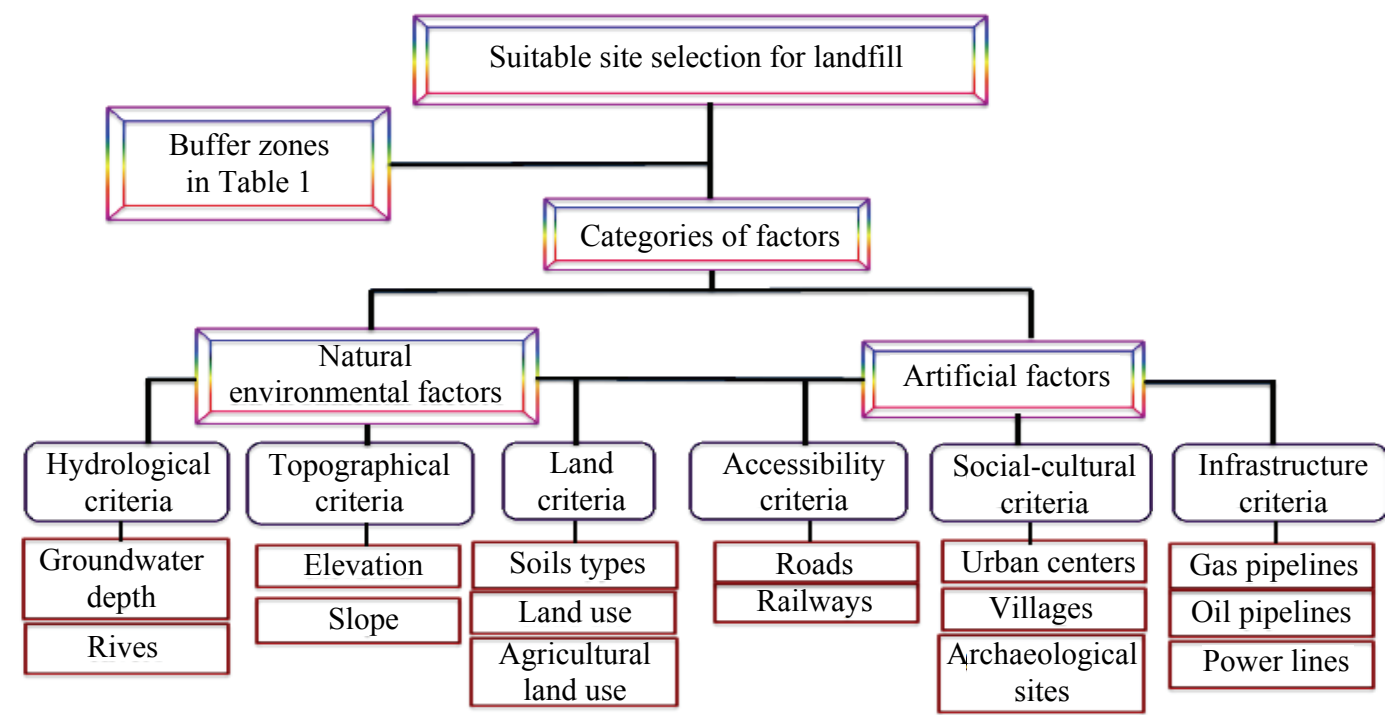

Fig. 2 Tree diagram of the decision process developed for selection of suitable landfill site. 
as well reducing environmental, economic and social costs [14]. Restricted sites mean areas which do not allow for a landfill site to be situated within them due to potential risk to the environment, human health or excessive cost [13]. Buffer zones, or spatial constraints, were used around important sites or specific geographic features in each criterion in the GIS environment using the special extension tool "buffer". Table 1 shows the buffer zones of the criteria for unsuitable areas that were used in landfill siting in Al-Qasim Qadhaa.

\subsection{Preparing Grading Values for Sub-criteria}

In this study, based on the opinion of experts and literature reviews in this field, as well as various required and available data about the study area, each criterion was classified into classes (sub-criteria), and each class was given a suitability grading value. This was carried out by decision makers who gave their opinions about the sub-criteria. In order to prepare each criterion and sub-criteria, a number of steps were performed in GIS (e.g., buffer, clip, extract, overlay, proximity, convert, reclassify and map algebra, etc.) (Table 2).

\subsubsection{Groundwater Depth}

To prepare the groundwater depths layer for Al-Qasim Qadhaa, the Kriging tool in GIS was used to generate an interpolation between the available data of groundwater depths in 170 wells throughout the Babylon Governorate [21]. These measurements were carried out from 2005 to 2013. Generally, the groundwater depths in the Babylon Governorate are shallow. These depths removed certain areas as appropriate for site selection for landfill because of a risk of contaminating the groundwater through leaching.

Various depths have been suggested as sufficient: Effat and Hegazy [27] suggested that a depth of $6 \mathrm{~m}$ from a site's surface to the groundwater table is a suitable depth, Delgado et al. [11] suggested $10 \mathrm{~m}$, Ouma et al. [41] propose $15 \mathrm{~m}$, and Sadek et al.[40] suggested $30 \mathrm{~m}$.

In this study, depths of between $0 \sim 1.5 \mathrm{~m}, 1.5 \sim 3 \mathrm{~m}$, $3 \sim 4.5 \mathrm{~m}$ and more than $4.5 \mathrm{~m}$ to groundwater were given a grading value of $1,4,6$ and 10, respectively (Fig. 3a).

\subsubsection{Rivers}

In this study, a distance less than 1,000 $\mathrm{m}$ from the boundaries of a river was given a score value of 0 to reduce the potential for river contamination from landfill. Distances greater than 1,000 $\mathrm{m}$ were given a grading value of 10 (Fig. 3b).

\subsubsection{Elevation}

This study adopted the DEM (digital elevation model) [21, 22]. The raster elevation map was divided into three categories according to the study area. In this

Table 1 Description of buffer zones criteria values.

\begin{tabular}{|c|c|c|}
\hline Criteria & Description & Researchers' suggested buffers \\
\hline Groundwater depth & $\begin{array}{l}\text { The zones of groundwater depth between } 0 \sim 1.5 \mathrm{~m} \text { should be avoided in } \\
\text { selection sites for landfill }\end{array}$ & $1.5 \mathrm{~m} \mathrm{[26];} 6 \mathrm{~m} \mathrm{[27];} 10 \mathrm{~m} \mathrm{[11]}$ \\
\hline Land use & $\begin{array}{l}\text { Industrial area, university and agricultural lands should be excluded from } \\
\text { land fillsiting }\end{array}$ & \\
\hline Rivers & Sites should be at a distance of more than $1 \mathrm{~km}$ from rivers & $1 \mathrm{~km}[7,28] ; 0.8 \mathrm{~km}[14] ; 0.5 \mathrm{~km}[29]$ \\
\hline Roads & Sites should be at a distance of more than $500 \mathrm{~m}$ from roads & $1 \mathrm{~km}[28,30] ; 0.5 \mathrm{~km}[27,31]$ \\
\hline Railways & Sites should be at a distance of more than $500 \mathrm{~m}$ from railways & $500 \mathrm{~m}[6,32,33]$ \\
\hline Urban centers & Sites should be at a distance of more than $5 \mathrm{~km}$ from streams & $5 \mathrm{~km}[27,33,34] ; 3 \mathrm{~km}[35]$ \\
\hline Villages & Sites should be at a distance of more than $1 \mathrm{~km}$ from borders of village & $1 \mathrm{~km}[31,36] ; 0.8 \mathrm{~km} \mathrm{[35]}$ \\
\hline Archaeological sites & Sites should be at a distance of more than $1 \mathrm{~km}$ around archaeological sites & $0.5 \mathrm{~km}[7] ; 1 \mathrm{~km}[13,37] ; 3 \mathrm{~km}[30]$ \\
\hline Gas pipelines & Sites should be at a distance of more than $300 \mathrm{~m}$ from gas pipelines & $250 \mathrm{~m}[33,38]$ \\
\hline Oil pipelines & Sites should be at a distance of more than $75 \mathrm{~m}$ from oil pipelines & $250 \mathrm{~m} \mathrm{[38]}$ \\
\hline Power lines & Sites should be at a distance of more than $30 \mathrm{~m}$ from power lines & $30 \mathrm{~m}[31,39] ; 40$ \\
\hline
\end{tabular}


Table 2 Summary of the input layers used in the analysis.

\begin{tabular}{|c|c|c|c|c|c|}
\hline No. & Criteria & Sub-criteria values & Sub-criteria rating & Description scale & Criteria weights (AHP) \\
\hline \multirow{4}{*}{1} & \multirow{4}{*}{ Groundwater depth (m) } & $0 \sim 1.5$ & 1 & Not suitable & \multirow{4}{*}{0.2004} \\
\hline & & $1.5 \sim 3$ & 4 & Moderately suitable & \\
\hline & & $3 \sim 4.5$ & 6 & Suitable & \\
\hline & & $>4.5$ & 10 & Most suitable & \\
\hline \multirow{2}{*}{2} & \multirow{2}{*}{ Rivers (m) } & $0 \sim 1,000$ & 0 & Not suitable & \multirow{2}{*}{0.1471} \\
\hline & & $>1,000$ & 10 & Most suitable & \\
\hline \multirow{3}{*}{3} & \multirow{3}{*}{ Elevation (a.m.s.l.) } & $15 \sim 22$ & 3 & Moderately suitable & \multirow{3}{*}{0.0709} \\
\hline & & $22 \sim 29$ & 7 & Suitable & \\
\hline & & $>29$ & 10 & Most suitable & \\
\hline 4 & Slope (degree) & $0^{\circ} \sim 5^{\circ}$ & 10 & Most suitable & 0.0463 \\
\hline \multirow{4}{*}{5} & \multirow{4}{*}{ Soils types } & Soil 6 (A) & 10 & Most suitable & \multirow{4}{*}{0.0709} \\
\hline & & Soil 5' (B) & 9 & Suitable & \\
\hline & & Soil 9 (C) & 7 & Moderately suitable & \\
\hline & & Soil 4 (D) & 5 & Less suitable & \\
\hline \multirow{9}{*}{6} & \multirow{9}{*}{ Land use } & Industrial area & 0 & Not suitable & \multirow{9}{*}{0.0302} \\
\hline & & Urban centers & 0 & Not suitable & \\
\hline & & Villages & 0 & Not suitable & \\
\hline & & University & 0 & Not suitable & \\
\hline & & Rivers & 0 & Not suitable & \\
\hline & & Archaeological sites & 0 & Not suitable & \\
\hline & & Agricultural lands & 0 & Not suitable & \\
\hline & & Orchards & 5 & Suitable & \\
\hline & & Unused lands & 10 & Most suitable & \\
\hline \multirow{3}{*}{7} & \multirow{3}{*}{ Agricultural land use } & Agricultural land & 0 & Not suitable & \multirow{3}{*}{0.0462} \\
\hline & & Orchards & 5 & Suitable & \\
\hline & & Unused land & 10 & Most suitable & \\
\hline \multirow{5}{*}{8} & \multirow{5}{*}{ Roads (m) } & $0 \sim 500$ & 0 & Not suitable & \multirow{5}{*}{0.0463} \\
\hline & & $500 \sim 1,000$ & 7 & Suitable & \\
\hline & & $1,000 \sim 2,000$ & 10 & Most suitable & \\
\hline & & $2,000 \sim 3,000$ & 5 & Moderately suitable & \\
\hline & & $>3,000$ & 3 & Less suitable & \\
\hline \multirow{2}{*}{9} & & $0 \sim 500$ & 0 & Not suitable & 00107 \\
\hline & Ra1lways (m) & $>500$ & 10 & Most suitable & 0.0101 \\
\hline & & $0 \sim 5,000$ & 0 & Not suitable & \\
\hline 10 & Urban centers $(m)$ & $5,000-10,000$ & 10 & Most suitable & 01471 \\
\hline 10 & Urban centers $(\mathrm{m})$ & $10,000 \sim 15,000$ & 7 & Suitable & $0.14 / 1$ \\
\hline & & $>15,000$ & 4 & Moderately suitable & \\
\hline 11 & Villages (m) & $0 \sim 1,000$ & 0 & Not suitable & 01038 \\
\hline 11 & V1llages (m) & $>1,000$ & 10 & Most suitable & 0.1038 \\
\hline & & $0 \sim 1,000$ & 0 & Not suitable & \\
\hline 12 & Archaeological sites (m) & $1,000 \sim 3,000$ & 5 & Moderately suitable & 0.0302 \\
\hline & & $>3,000$ & 10 & Most suitable & \\
\hline 13 & Gas nipelines (m) & $\leq 300$ & 0 & Not suitable & 00146 \\
\hline 13 & Gas pipelines (m) & $>300$ & 10 & Most suitable & 0.0146 \\
\hline 14 & Oil nipelines $(\mathrm{m})$ & $\leq 75$ & 0 & Not suitable & 00146 \\
\hline 14 & O1l pipelines (m) & $>75$ & 10 & Most suitable & 0.0146 \\
\hline 15 & Power lines (m) & $\begin{array}{l}\leq 30 \\
>30\end{array}$ & $\begin{array}{l}0 \\
10\end{array}$ & $\begin{array}{l}\text { Not suitable } \\
\text { Most suitable }\end{array}$ & 0.0207 \\
\hline
\end{tabular}

Note: AHP: analytical hierarchy process; a.m.s.l.: above mean sea level. 


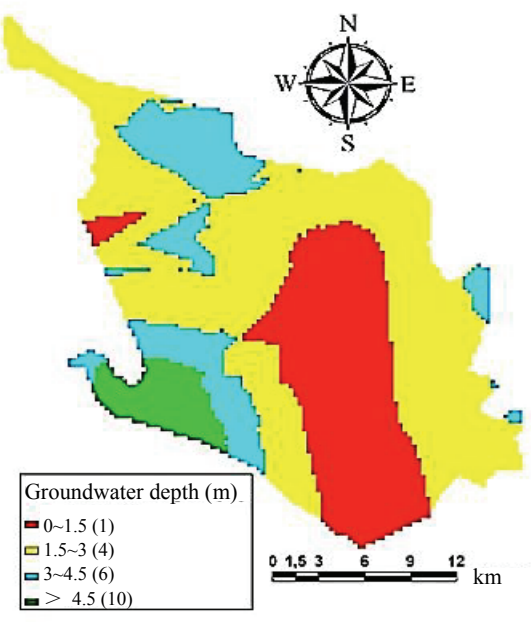

(a)

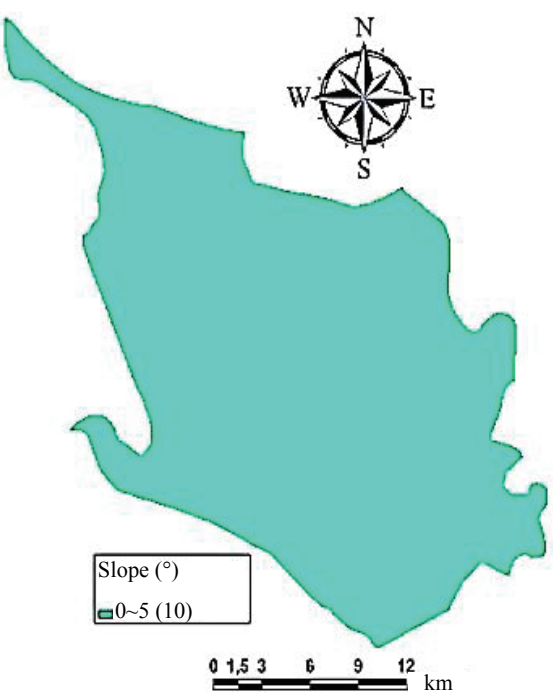

(d)

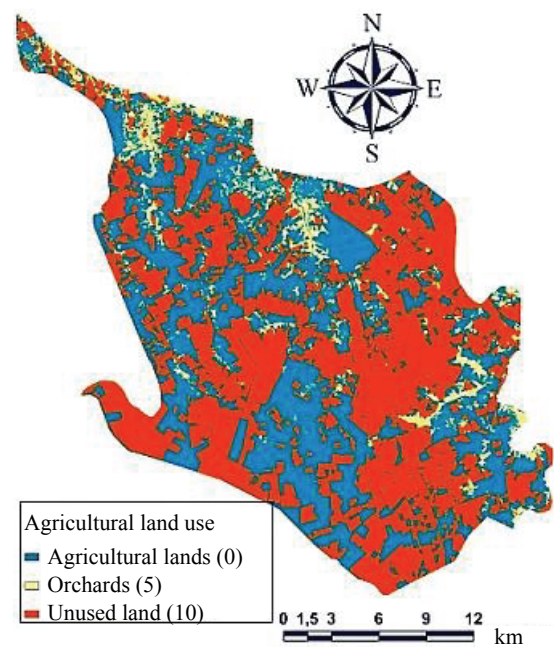

(g)

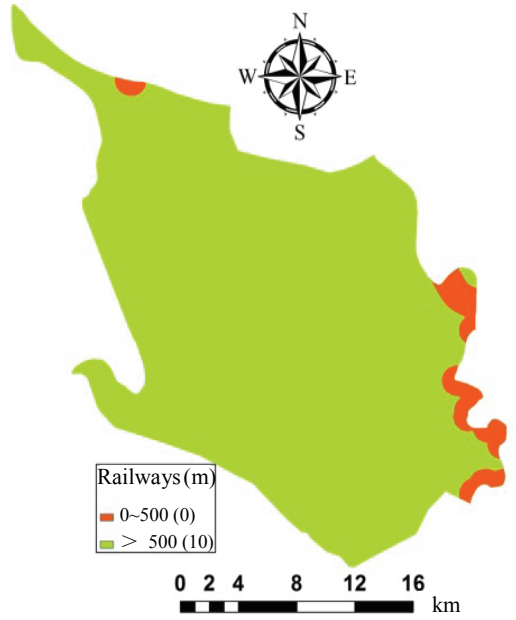

(b)

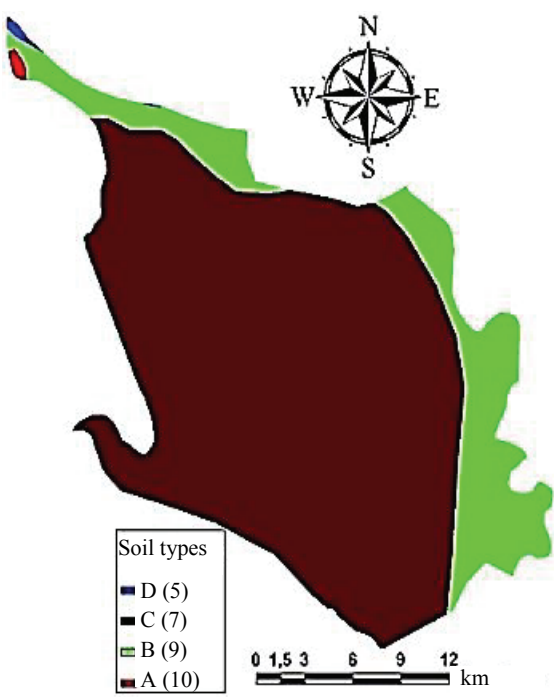

(e)

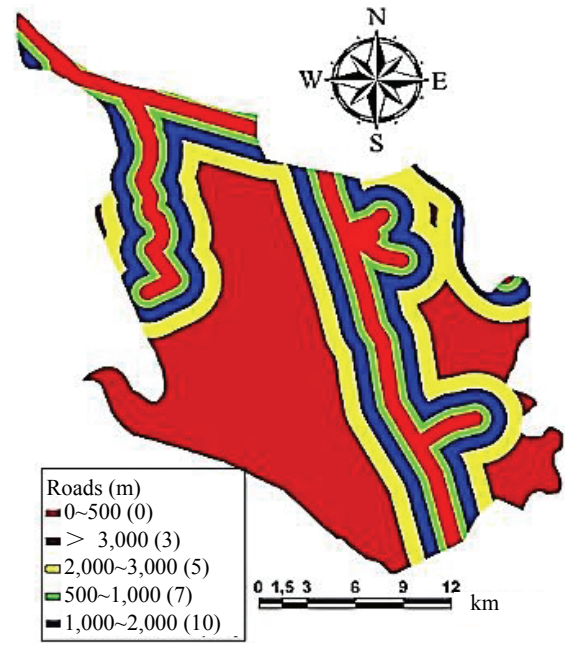

(h)

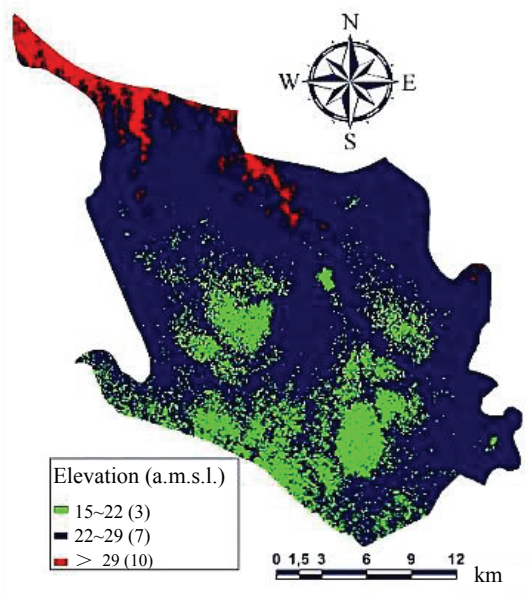

(c)

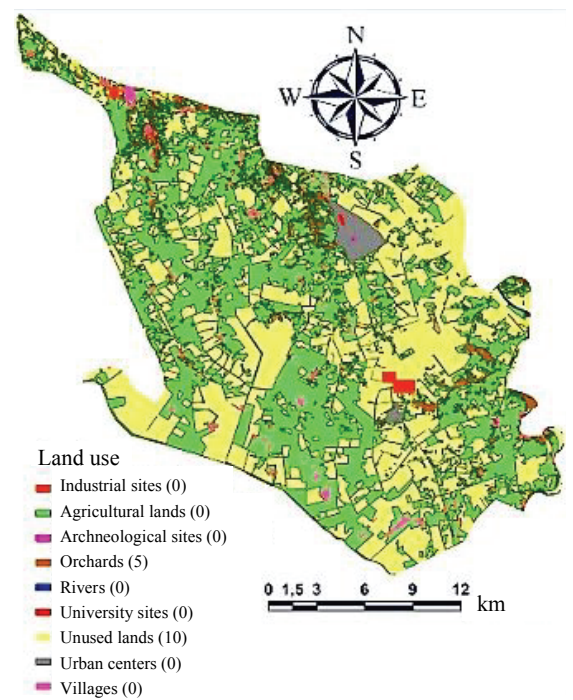

(f)

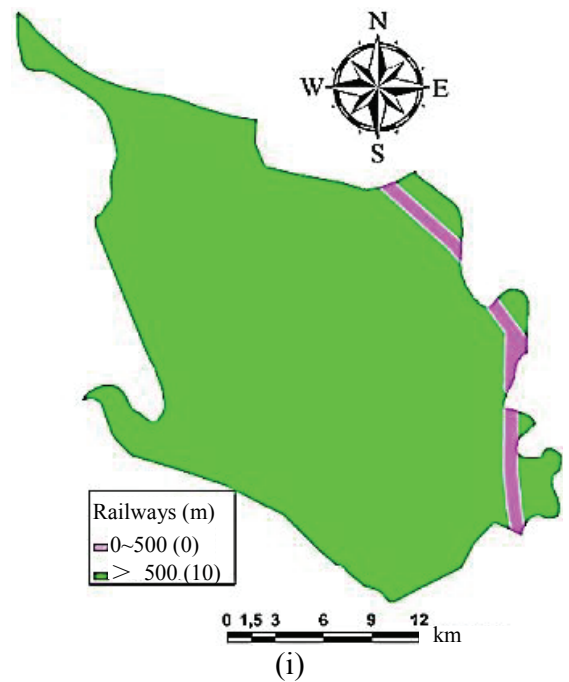

Fig. 3 Suitability index maps of: (a) ground water depth; (b) rivers; (c) elevation; (d) slope; (e) soil types; (f) land use; (g) agricultural land use; (h) roads; (i) railways. 
study, moderately suitable elevations were between 15 22 (a.m.s.1.) and between 22 29 (a.m.s.1.). Elevations of greater than 29 (a.m.s.l.) were the most suitable for a landfill. These categories were given grading values of 3, 7 and 10, respectively (Fig. 3c).

\subsubsection{Slope}

All lands of Al-Qasim Qadhaa have a slope less than $5^{\circ}$ and so were given a rating value of 10 (Fig. $3 \mathrm{~d}$ ). These lands were considered the best for a landfill siting to prevent the transition of pollutants to surrounding areas. A suitable slope ranges between $0^{\circ} \sim 5^{\circ}$ is necessary to prevent the transition of pollutants to surrounding areas $[13,33]$.

\subsubsection{Soil Type}

There are four types of soils in Qasim Qadhaa Buringh (1960) (Fig. 3e). These soil groups are: basin depression soils A (6), river basin soils, poorly drained B (5'), silted haur and marsh soils C (9) and river levee soils D (4). These types of soils were giving scores of 10, 9, 7 and 5, respectively. The short description of the characteristics for each type of soil can be found in Refs. [22, 42].

\subsubsection{Land Use}

A number of maps were incorporated to prepare the land use layer of the study area. All land classified into one of nine categories (features): urban centers, villages, industrial areas, archaeological sites, universities, rivers, agricultural land, orchards and unused land. The land use layer was created by importing shape files for all categories into a GIS environment in polygon type. The shape file of "urban" included all cities in Al-Qasim Qadhaa. The villages which spread within this Qadhaa were incorporated in the shape file of "villages". The "agricultural land" shape file was created by analyzing satellite images of the Babylon Governorate in 2011 and the land capability map of Iraq (scale 1:1,000,000). The shape file of the Green University of Al Qasim was mapped in polygon type from satellite images of the Babylon Governorate in 2011. The maps used had scales of $1: 400,000$ and $1: 1,500,000$ to determine the shape files for industrial areas and archaeological sites, respectively. The shape file of "Al-Qasim Qadhaa rivers" was a clipping from the shape file of "Babylon Governorate rivers". All shape files were merged into a single layer called "land use". The categories of "orchards" and "unused lands" were given ratings of 5 and 10, respectively, while other categories were assigned a score of 0 (Fig. 3f).

\subsubsection{Agricultural Land Use}

The lands for Al-Qasim Qadhaa were divided into three categories: agricultural land, orchards and unused lands. The categories of orchards and unused lands were drawn in polygon type in separate shape files based on analyzed satellite images of the Babylon Governorate in 2011 [23] and the land capability map of Iraq (scale 1:1,000,000 ) [43]. In order to prepare the features of "agricultural land", the features of "orchards" and "unused land" were merged into one feature. Then, the special extension tool "erase" in GIS was used to extract the areas of agricultural land. These features were then merged into a single shape file and then converted to a raster map called "agricultural land use" (Fig. 3g). The categories of "unused land", "orchards" and "agricultural land" were given a grade of 10,5 , and 0 , respectively, according to the classification of the Iraqi Ministry of Agriculture.

\subsubsection{Roads}

In this study, main roads and highways were incorporated into the layer of "roads". Buffer zones from roads to landfill sites of 1,000 2,000 m were assigned the highest score of 10. Buffer zones of less than $500 \mathrm{~m}$, and those greater than $3,000 \mathrm{~m}$, were given a grading of 0 and 3 , respectively. Buffer zones of $500 \sim 1,000 \mathrm{~m}$ were assigned a grade of 7 , while the buffer zones of 2,000 3,000 $\mathrm{m}$ were given a grading of 5 (Fig. 3h).

\subsubsection{Railway}

In this study, buffer zones of less than $500 \mathrm{~m}$ on both sides of a railway were graded 0 . Distances greater than $500 \mathrm{~m}$ were graded 10 (Fig. 3i). 


\subsubsection{Urban Centers}

To determine suitable locations for landfill from borders of urban areas, buffer zones of less than $5 \mathrm{~km}$ were given a grading of 0 . This figure was adopted due to many factors such as land value, health and safety laws (which often prevent siting of a landfill within the boundaries of an urban area) noise, decreases in property value [44], odor, aesthetics [45] and allowances for ensuring the potential to expand the urban area in the future [27].

Buffer zones between $5 \sim 10 \mathrm{~km}$ were given the highest score which was 10 . Buffer zones of $10 \sim 15 \mathrm{~km}$ and more than $15 \mathrm{~km}$ were given a score of 7 and 4 , respectively (Fig. 4a).

\subsubsection{Villages}

For rural areas, buffer zones less than 1,000 m were given a grading value of 0 , while those with buffer zones greater than $1,000 \mathrm{~m}$ were given a score of 10 (Fig. 4b).

\subsubsection{Archaeological Sites}

For archaeological and religious sites, buffer zone of less than $1 \mathrm{~km}$ around these areas was restricted and, thus, scored 0 . Buffer zones more than $3 \mathrm{~km}$, and buffer zones of $1 \sim 3 \mathrm{~km}$ around these areas were scored 10 and 5 , respectively (Fig. 4c).

\subsubsection{Gas Pipelines}

The necessary buffer zone from gas pipelines on both sides to a landfill site was $300 \mathrm{~m}$, and it was given a grading value of 0 according to the determinations of the Iraqi Ministry of Oil/Oil Pipelines Company in 1989 [46]. Buffer zones more than $300 \mathrm{~m}$ were given a score value of 10 (Fig. 4d).

\subsubsection{Oil Pipelines}

Buffer zones less than $75 \mathrm{~m}$ on both sides of oil pipelines to a landfill site were giving a score of 0 . Buffer zones more than $75 \mathrm{~m}$ are considered a safe distance according to the determinations of the Iraqi Ministry of Oil/Oil Pipelines Company in 1989 [46], and were given a grading value of 10 (Fig. 4e).

\subsubsection{Power Lines}

In this study, buffer zones from a landfill site to power lines on both sides should be more than $30 \mathrm{~m}$, and these were given a score of 10 . The reasons for choosing this value were to avoid the high level of voltage power that results from these lines, and to provide electricity for the infrastructure in a landfill site [33, 39]. Distances less than $30 \mathrm{~m}$ was given a grading of 0 (Fig. 4f).

\subsection{Evaluation Criteria's Weights Using AHP Method}

The AHP developed in 1980 by Saaty [12], is a powerful and comprehensive decision-making methodology. It is one of the most common methods applied to multi-criteria in making decisions. This process allows a decision maker to make the right decision by using empirical data alongside the subjective judgments of the decision maker [13, 47].

In the AHP method, the hierarchy is deconstructed into a series of pair-wise comparisons to determine the relative weighted importance of each criterion in terms of the other criteria. A 9-point numerical scale is used in a typical analytic hierarchy in order to indicate how many times more important or how dominant one criterion is over another criterion with respect to the criteria. This scale was presented by Saaty [12] in 1980 and further developed in 2008 [48] (Table 3).

In this study, the typical structure of the decision-making problem is formed and consists of numbers, which were represented by symbol $m$, while alternatives were given numbers represented by symbol $n$. The values of $a_{i j}(i=1,2,3 \ldots, m)$ and $(j=1$, $2,3 \ldots, n)$ are used to signify the performance values in terms of the $i$-th and $j$-th in a matrix. The upper triangular of the matrix is filled with the values of comparison criteria above the diagonal of the matrix. In order to fill the lower triangular of the matrix, the reciprocal values of the upper diagonal are used. This is done by using the Eq. (1):

$$
a_{j i}=1 / a_{i j}
$$

where, $a_{i j}$ is the element of row $i$ and column $j$ of the matrix $[17,49,50]$. The typical comparison matrix for any problem and the relative importance of the criteria 


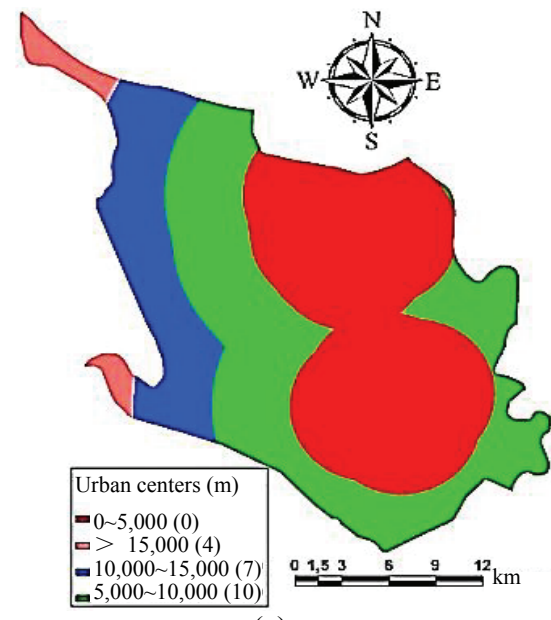

(a)

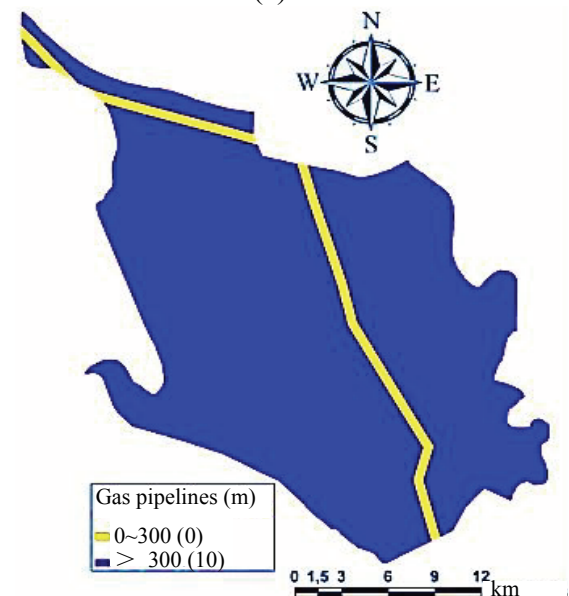

(d)

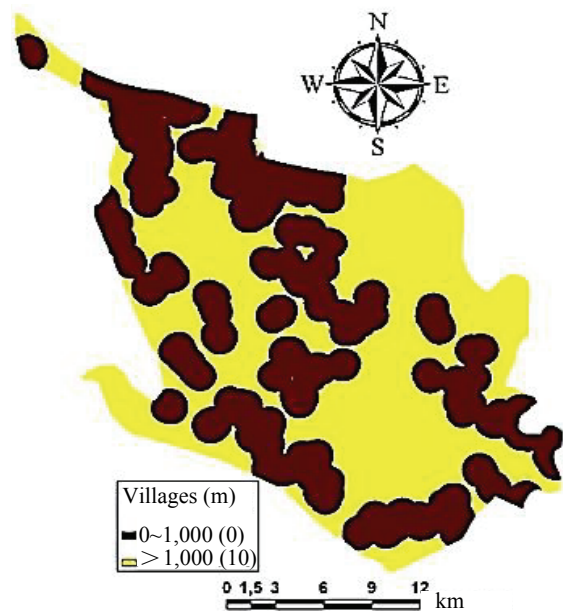

(b)

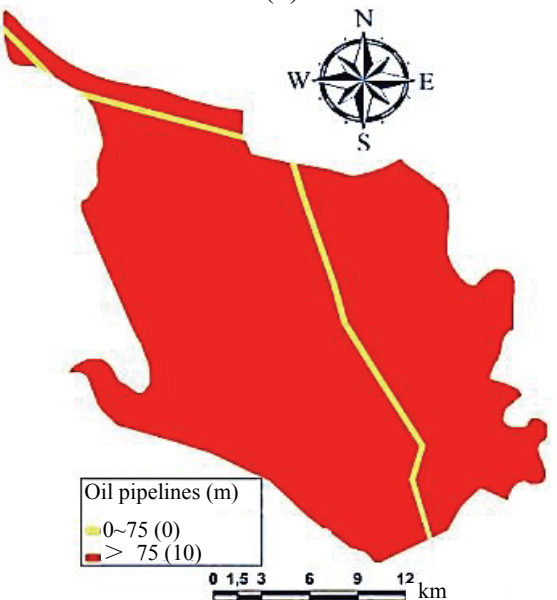

(e)

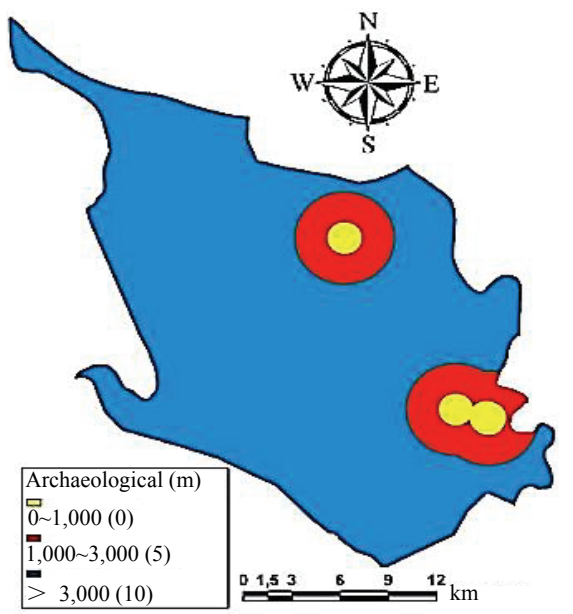

(c)

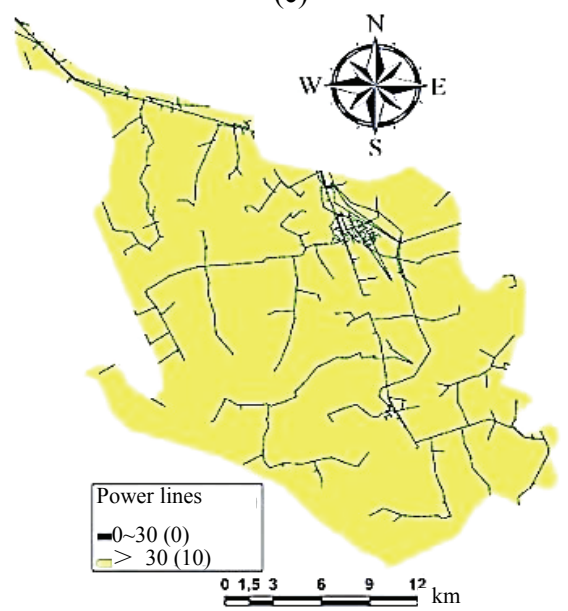

(f)

Fig. 4 Suitability index maps of: (a) urban centers; (b) villages; (c) archaeological sites; (d) gas pipelines; (e) oil pipelines; (f) power lines.

Table 3 The fundamental scale of absolute numbers [48].

\begin{tabular}{lll}
\hline Intensity of importance & Definition & Explanation \\
\hline 1 & Equal importance & Two activities contribute equally to the objective \\
2 & Weak or slight & \\
3 & Moderate importance & Experience and judgment slightly favour one activity over another \\
4 & Moderate plus & \\
5 & Strong importance & Experience and judgment strongly favour one activity over another \\
6 & Strong plus & An activity is favored very strong over another; Its dominance demonstrated \\
7 & Very strong or & demonstrated importance \\
8 & Very, very strong & $\begin{array}{l}\text { in practice } \\
\text { The evidencefavoring one activity over another is of the highest possible } \\
9\end{array}$ \\
\hline
\end{tabular}

can be represented in a decision matrix as follows:

$\left(\begin{array}{ccccc}\mathrm{a}_{11} & \mathrm{a}_{12} & \ldots & \mathrm{a}_{1 \mathrm{n}} & W_{1} \\ \mathrm{a}_{21} & \mathrm{a}_{22} & \ldots & \mathrm{a}_{2 \mathrm{n}} & W_{2} \\ \ldots & \ldots & \ldots & \ldots & \ldots \\ \mathrm{a}_{\mathrm{m} 1} & \mathrm{a}_{\mathrm{m} 2} & \ldots & \mathrm{a}_{\mathrm{mn}} & W_{\mathrm{n}}\end{array}\right)$
The eigenvectors were calculated for each row using geometric principles in Eq. (2):

$$
E g_{i}=\sqrt[n]{a_{11} \times a_{12} \times a_{13} \times \ldots \times a_{1 n}}
$$

where, $E g_{i}=$ eigenvalue for the row $i ; n=$ number of 
elements in row $i$.

The priority vector was determined by normalizing the eigenvalues to 1 (divided by their sum) as follows:

$$
P r_{i}=E g_{i} /\left(\sum_{k=1}^{n} E g_{k}\right)
$$

The lambda $\max \left(\lambda_{\max }\right)$ was obtained from the summation of products between each element of the priority vector and the sum of columns of the reciprocal matrix as shown in the following Eq. (4):

$$
\lambda_{\max }=\sum_{j=1}^{n}\left[W_{j} \times \sum_{i=1}^{m} a_{i j}\right]
$$

where, $a_{i j}=$ the sum of criteria in each column in the matrix; $W_{i}=$ the value of weight for each criterion corresponding to the priority vector in the matrix of decision, where the values $i=1,2, \ldots m$, and $j=1,2, \ldots$ $n$. So, the lambda $\max \left(\lambda_{\max }\right)$ in this study is equal to 15.6 .

The $C I$ (consistency index) was estimated using the following Eq. (5):

$$
C I=\left(\lambda_{\max }-n\right) /(n-1)
$$

where, $C I$ represents the equivalent to the mean deviation of each comparison element and the standard deviation of the evaluation error from the true ones [51], and $n$ is size or order of the matrix. In this study, $C I=0.04$.

The $C R$ (consistency ratio) was obtained based on
Saaty [12], by dividing the value of $C I$ by the $R I$ (random index) value $(R I=15.9)$ for $n=15$ (Table 4), where Table 4 displays mean $R I$ for matrices with different sizes [34, 52]:

$$
C R=C I / R I
$$

If the value of $C R$ is smaller than $10 \%$, the ratio indicates a reasonable consistency level in the pair-wise comparison. In this study, $C R=0.027<0.1$ and $R I_{15}=1.59$. For any matrix, the judgments are completely consistent if a $C R$ is equal to 0 [53]. Fig. 5 shows the pair-wise comparison matrix and relative importance weights for the selection site for landfill in the study area.

In order to find the suitability index value of the potential areas, the method of WLC (weighted linear combination) was used based on the following Eq. (7):

$$
A_{i}=\sum_{j=1}^{n} W_{j} \times C_{i j}
$$

where, $A_{i}$ is the suitability index for area $i, W_{j}$ is the relative importance weight of criterion, $C_{i j}$ is the grading value of area $i$ under criterion $j$ and $n$ is the

\begin{tabular}{|c|c|c|c|c|c|c|c|c|c|c|c|c|c|c|c|}
\hline$n$ & 1 & 2 & 3 & 4 & 5 & 6 & 7 & 8 & 9 & 10 & 11 & 12 & 13 & 14 & 15 \\
\hline$R I$ & 0 & 0 & 0.58 & 0.9 & 1.12 & 1.24 & 1.32 & 1.41 & 1.45 & 1.49 & 1.51 & 1.48 & 1.56 & 1.57 & 1.59 \\
\hline
\end{tabular}
total number of criteria $[7,30]$.

This Eq. (7) was applied on all criteria using the extension tool "map algebra" in GIS. The procedures

Table 4 Random inconsistency indices for different values of $n[36,54]$.

\begin{tabular}{|c|c|c|c|c|c|c|c|c|c|c|c|c|c|c|c|c|c|}
\hline & $\mathrm{A}$ & $\mathrm{B}$ & $\mathrm{C}$ & $\mathrm{D}$ & $\mathrm{E}$ & $\mathrm{F}$ & $\mathrm{G}$ & $\mathrm{H}$ & $\mathrm{I}$ & $\mathrm{J}$ & $\mathrm{K}$ & $\mathrm{L}$ & $\mathrm{M}$ & $\mathrm{N}$ & $\mathrm{O}$ & $\begin{array}{c}\text { Eigen } \\
\text { vector }\end{array}$ & $\begin{array}{c}\text { Normalized } \\
\text { weights }\end{array}$ \\
\hline $\mathrm{A}$ & 1 & 2 & 3 & 2 & 4 & 5 & 5 & 4 & 8 & 8 & 7 & 6 & 5 & 6 & 9 & 4.33 & 0.2004 \\
\hline $\mathrm{B}$ & 0.50 & 1 & 2 & 1 & 3 & 4 & 4 & 3 & 7 & 7 & 6 & 5 & 4 & 5 & 8 & 3.18 & 0.1471 \\
\hline $\mathrm{C}$ & 0.33 & 0.50 & 1 & 0.5 & 2 & 3 & 3 & 2 & 6 & 6 & 5 & 4 & 3 & 4 & 7 & 2.24 & 0.1038 \\
\hline $\mathrm{D}$ & 0.50 & 1.00 & 2.00 & 1 & 3 & 4 & 4 & 3 & 7 & 7 & 6 & 5 & 4 & 5 & 8 & 3.18 & 0.1471 \\
\hline $\mathrm{E}$ & 0.25 & 0.33 & 0.50 & 0.33 & 1 & 2 & 2 & 1 & 5 & 5 & 4 & 3 & 2 & 3 & 6 & 1.53 & 0.0709 \\
\hline F & 0.20 & 0.25 & 0.33 & 0.25 & 0.50 & 1 & 1 & 0.5 & 4 & 4 & 3 & 2 & 1 & 2 & 5 & 1.00 & 0.0463 \\
\hline $\mathrm{G}$ & 0.20 & 0.25 & 0.33 & 0.25 & 0.50 & 1.00 & 1 & 0.5 & 4 & 4 & 3 & 2 & 1 & 2 & 5 & 1.00 & 0.0463 \\
\hline H & 0.25 & 0.33 & 0.50 & 0.33 & 1.00 & 2.00 & 2.00 & 1 & 5 & 5 & 4 & 3 & 2 & 3 & 6 & 1.53 & 0.0709 \\
\hline I & 0.13 & 0.14 & 0.17 & 0.14 & 0.20 & 0.25 & 0.25 & 0.20 & 1 & 1 & 0.5 & 0.34 & 0.25 & 0.34 & 2 & 0.32 & 0.0146 \\
\hline J & 0.13 & 0.14 & 0.17 & 0.14 & 0.20 & 0.25 & 0.25 & 0.20 & 1.00 & 1 & 0.5 & 0.34 & 0.25 & 0.34 & 2 & 0.32 & 0.0146 \\
\hline K & 0.14 & 0.17 & 0.20 & 0.17 & 0.25 & 0.33 & 0.33 & 0.25 & 2.00 & 2.00 & 1 & 0.5 & 0.34 & 0.5 & 3 & 0.45 & 0.0207 \\
\hline L & 0.17 & 0.20 & 0.25 & 0.20 & 0.33 & 0.50 & 0.50 & 0.33 & 2.94 & 2.94 & 2.00 & 1 & 0.5 & 1 & 4 & 0.65 & 0.0302 \\
\hline M & 0.20 & 0.25 & 0.33 & 0.25 & 0.50 & 1.00 & 1.00 & 0.50 & 4.00 & 4.00 & 2.94 & 2.00 & 1 & 2 & 5 & 1.00 & 0.0462 \\
\hline N & 0.17 & 0.20 & 0.25 & 0.20 & 0.33 & 0.50 & 0.50 & 0.50 & 2.94 & 2.94 & 2.00 & 1.00 & 0.50 & 1 & 4 & 0.65 & 0.0302 \\
\hline O & 0.11 & 0.13 & 0.14 & 0.13 & 0.17 & 0.20 & 0.20 & 0.33 & 0.50 & 0.50 & 0.33 & 0.25 & 0.20 & 0.25 & 1 & 0.23 & 0.0107 \\
\hline
\end{tabular}

Fig. 5 Pair-wise comparisons matrix for selecting a suitable landfill site, eigenvector and significance weights.

Note: A: groundwater depth; B: urban centers; C: villages; D: rivers; E: elevation; F: slope; G: roads; H: soils types; I: gas pipelines; J: oil pipelines; K: power lines; L: land use; M: agricultural land use; N: archaeological sites; O: railways. 
for estimating the suitability index were done through the summation of the products of multiplying the grading values of the sub-criteria for each criterion (based on the opinion of experts in this field) by the corresponding relative importance weight (which was calculated by the AHP method). The final value of suitability index was obtained according to the grading scale of $1 \sim 5$, which was ranging from the lowest value of an unsuitable site to the highest value of the most suitable for a site [30].

\section{Results and Discussion}

After determining the weights for each criterion using the AHP method, suitable weightings for the sub-criteria of each criterion based on the opinion of experts in this field were assigned. The WLC method was used to determine the final output map of the suitability index for a landfill siting in Al-Qasim Qadhaa. This map was divided into five categories:

- unsuitable;

- moderately suitable;

- suitable;

- most suitable;

- excluded areas.

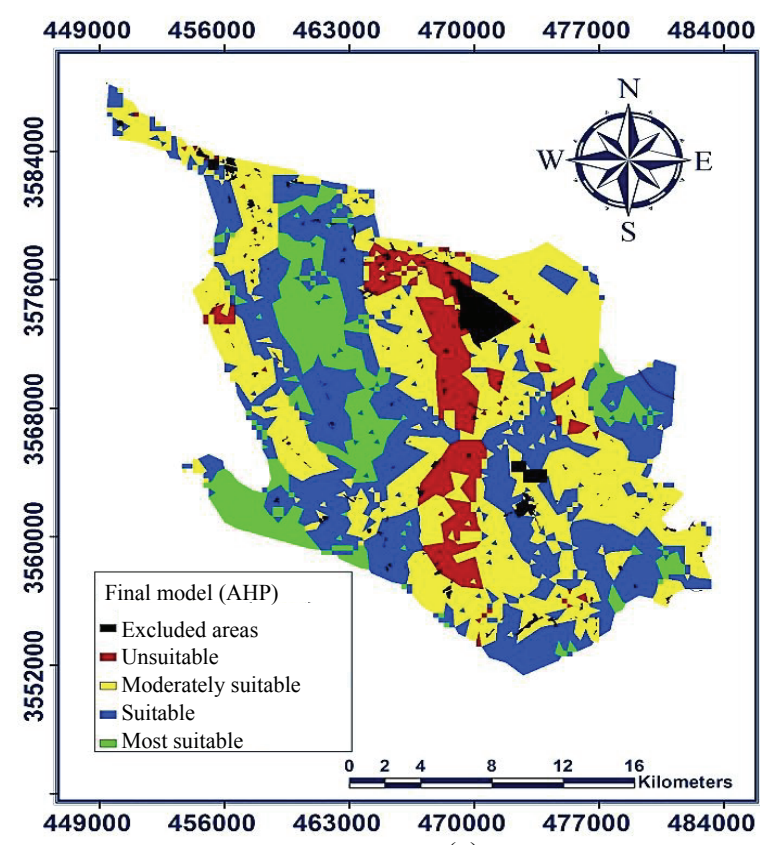

(a)
The category of "excluded areas" included urban centers, villages, rivers, archaeological sites, a university location and industrial areas. These areas were given a value of 0 . The area for each category and its proportion of the total study area were as follows:

- The "unsuitable" class is $50.76 \mathrm{~km}^{2}(8.74 \%)$;

- The "moderately suitable" class is $234.46 \mathrm{~km}^{2}$ $(40.38 \%)$;

- The "suitable" class is $206.47 \mathrm{~km}^{2}$ (35.56\%);

- The "most suitable" class is $70.92 \mathrm{~km}^{2}$ (12.22\%);

- The "excluded areas" is $17.97 \mathrm{~km}^{2}$ (3.1\%) (Fig. 6a).

The solid waste quantity expected in 2030 in Al-Qasim Qadhaa is 71,947 t. The cumulative quantity of solid waste expected from 2020 to 2030 is $632,990 \mathrm{t}$ based on an expected population in 2030 in this Qadhaa of 304,621 inhabitants, according to calculations made by Chabuk et al. [54]. The density of waste in waste disposal sites is $450 \mathrm{~kg} / \mathrm{m}^{3}$ in the Babylon Governorate and, consequently, in Al-Qasim Qadhaa [55]. By dividing the solid waste quantity over the density of waste, the expected volume of waste and the predictable volume of cumulative waste in 2030 are $159,882 \mathrm{~m}^{3}$ and $1,406,644 \mathrm{~m}^{3}$, respectively. An average groundwater depth of $2 \mathrm{~m}$ in the candidate

Fig. 6 Final maps of suitability index for landfill sitting: (a) final model map of a suitable landfill; (b) the candidate sites for landfill in Al-Qasim Qadhaa. 
sites for landfill in the study area was adopted because the groundwater depth from a ground surface in Al-Qasim Qadhaa is shallow. Therefore, the required area of a candidate site to accommodate the cumulative quantity of solid waste generated from 2020 to 2030 is $0.702 \mathrm{~km}^{2}$.

Two candidate sites were selected for landfill among the many sites located within the category of the "most suitable" index. These sites were each assigned a number (1 and 2). The area of Site No. 1 is $2.766 \mathrm{~km}^{2}$, while the area of Site No. 2 is $2.055 \mathrm{~km}^{2}$. These candidate sites are suitable for landfill in Al-Qasim Qadhaa. Fig. 6b shows that Site No.1 is situated at latitude $32^{\circ} 11^{\prime} 43^{\prime \prime} \mathrm{N}$, and longitude $44^{\circ} 32^{\prime} 26^{\prime \prime} \mathrm{E}$, while Site No. 2 is situated at latitude $32^{\circ} 14^{\prime} 38^{\prime \prime} \mathrm{N}$, and longitude $44^{\circ} 37^{\prime} 10^{\prime \prime} \mathrm{E}$.

\section{Conclusions}

This study aimed to select suitable sites for landfill in Al-Qasim Qadhaa using the best methodology and also by taking into account the scientific and environmental criteria which are followed in advanced countries. In order to determine the most suitable site for solid waste landfill in Al-Qasim Qadhaa, 15 layers were incorporated in the process of analysis using GIS, which is considered a powerful tool for assisting in the selection of a site for landfill due to its ability to deal with a large volume of data from different sources. Here, these layers were groundwater depth, rivers, soil types, agriculture land, land use, elevation, slope, gas pipelines, oil pipelines, power lines, roads, railways, urban centers, villages and archaeological sites. An AHP was used to derive the weightings for multi-criteria using a pair-wise comparison to construct a comparison matrix. Then, a WLC method was used to produce a suitability index for the final output map for the study area.

Finally, in the category of "most suitable" on the final map, two candidate sites were identified for landfill among several sites. These sites were checked on the satellite images (2011) of the Babylon
Governorate to make sure that these sites were suitable for landfill. Generally, these sites satisfy the minimum requirements of the landfill sites. The area of Sites No. 1 and No. 2 are 2.766 and $2.055 \mathrm{~km}^{2}$, respectively. The required area in the present study that can well accommodate such waste was $0.702 \mathrm{~km}^{2}$. This area was estimated based on expected solid waste for the period 2020 to 2030 as $632,990 \mathrm{t}$ and was also based on the current waste generation rate and population growth rate in this Qadhaa, which were $0.58 \mathrm{~kg}$ per capita day, and 2.99\%, respectively.

\section{References}

[1] Alavi Moghadam, M. R., Mokhtarani, N., and Mokhtarani, B. 2009. "Municipal Solid Waste Management in Rasht City, Iran." Waste Management 29 (1): 485-9.

[2] Moeinaddini, M., Khorasani, N., Danehkar, A., Darvishsefat, A. A., and Zienalyan, M. 2010. "Siting MSW Landfill Using Weighted Linear Combination and Analytical Hierarchy Process (AHP) Methodology in GIS Environment (Case Study: Karaj)." Waste Management 30 (5): 912-20.

[3] Kim, K. R., and Owens, G. 2010. "Potential for Enhanced Phytoremediation of Landfills Using Biosolids: A Review." Journal of Environmental Management 91 (4): 791-7.

[4] Brockerhoff, M. 2000. "An Urbanizing World." Population Reference Bureau 55 (3): 1-46.

[5] Proske, H., Vlcko, J., Rosenbaum, M. S., Dorn, M., Culshaw, M., and Marker, B. 2005. "Special Purpose Mapping for Waste Disposal Sites." Bull Engineering Geology Environment 64 (1): 1-54.

[6] Nas, B., Cay, T., Iscan, F., and Berktay, A. 2010. "Selection of MSW Landfill Site for Konya, Turkey Using GIS and Multi-criteria Evaluation." Environmental Monitoring and Assessment 160 (1-4): 491-500.

[7] Eskandari, M., Homaee, M., and Mahmodi, S. 2012. "An Integrated Multi Criteria Approach for Landfill Siting in a Conflicting Environmental, Economical and Socio-Cultural Area." Waste Management 32 (8): 1528-38.

[8] Lin, H., and Kao, J. 1999. "Enhanced Spatial Model for Landfill Siting Analysis." Journal of Environmental Engineering 125 (9): 845-51.

[9] Javaheri, H., Nasrabadi, T., Jafarian, M. H., Rowshan, G. R., and Khoshnam, H. 2006. "Site Selection of Municipal Solid Waste Landfills Using Analytical Hierarchy Process Method in a Geographical Information Technology 
Environment in Giroft." Journal of Environmental Health Science \& Engineering 3 (3): 177-84.

[10] Kontos, T. D., Komilis, D. P., and Halvadakis, C. P. 2003. "Siting MSW Landfills on Lesvos Island with a GIS Based Methodology." Waste Management \& Research 21 (3): 262-77.

[11] Delgado, O. B., Mendoza, M., Granados, E. L., and Geneletti, D. 2008. "Analysis of Land Suitability for the Siting of Inter-municipal Landfills in the Cuitzeo Lake Basin, Mexico." Waste Management 28 (7): 1137-46.

[12] Saaty, T. L. 1980. The Analytic Hierarchy Process: Planning, Priority Setting, Resources Allocation. New York: McGraw.

[13] Ersoy, H., and Bulut, F. 2009. "Spatial and Multi-criteria Decision Analysis-Based Methodology for Landfill Site Selection in Growing Urban Regions." Waste Management \& Research 27 (5): 489-500.

[14] Siddiqui, M. Z., Everett, J. W., and Vieux, B. E. 1996. "Landfill Siting Using Geographic Information Systems: A Demonstration." Journal of Environmental Engineering 122 (6): 515-23.

[15] Kao, J., and Lin, H. 1996. "Multifactor Spatial Analysis for Landfill Siting." Journal of Environmental Engineering 122 (10): 902-8.

[16] Melo, A. L., Calijuri, M. L., Duarte, I. C., Roberto, F., Azevedo, R. F., and Lorentz, J. F. 2006. "Strategic Decision Analysis for Selection of Landfill Sites.” Journal of Surveying Engineering 132 (2): 83-92.

[17] Şener, Ş., Sener, E., and Karagüzel, R. 2011. "Solid Waste Disposal Site Selection with GIS and AHP Methodology: A Case Study in Senirkent-Uluborlu (Isparta) Basin, Turkey." Environmental Monitoring and Assessment 173 (1-4): 533-54.

[18] Gorsevski, P. V., Donevska, K. R., Mitrovski, C. D., Joseph P., and Frizado, J. P. 2012. "Integrating Multi-criteria Evaluation Techniques with Geographic Information Systems for Landfill Site Selection: A Case Study Using Ordered Weighted Average." Waste Management 32 (2): 287-96.

[19] Iraqi Ministry of Municipalities and Public Works. 2009. Structural Plan of Babylon Governorate. Baghdad: Iraqi Ministry of Municipalities and Public Works.

[20] Iraqi Ministry of Planning. 2015. Records of Directorate of Census Babylon. Baghdad: Iraqi Ministry of Planning.

[21] Iraqi Ministry of Water Resources. 2015. General Commission for Groundwater. Rusafa: Iraqi Ministry of Water Resources.

[22] Buringh, P. 1960. Soils and Soil Conditions in Iraq. Baghdad: The Ministry of Agriculture.

[23] Iraqi Ministry of Municipalities and Public Works. 2011. Directorate of Sewage Babylon. Internal report.

[24] World Digital Library. 2013. "The Archaeological Map of
Iraq." World Digital Library. Accessed September 24, 2013. http://www.wdl.org/en/item/212/.

[25] Chabuk, A., Al-Ansari, N., Hussain, H. M., Knutsson, S., and Pusch, R. 2016. "Selection a Suitable Site for Landfill Using Geographic Information System and Multi-criteria Evaluation Methods: A Case Study Al-Musayiab Qadhaa, Babylon, Iraq." Journal of Environmental Engineering Science. (to be published)

[26] Alves, M., Lima, B., Evsukoff, A., and Vieira, I. 2009. "Developing a Fuzzy Decision Support System to Determine the Location of a Landfill Site." Waste Management \& Research 27: 641-51.

[27] Effat, H. A., and Hegazy, M. N. 2012. "Mapping Potential Landfill Sites for North Sinai Cities Using Spatial Multi-criteria Evaluation." The Egyptian Journal of Remote Sensing and Space Science 15 (2): 125-33.

[28] Sharifi, M., Mosslem, H. M., Vessali, E., Mosstafakhani, P., Taheri, K., Shahoie, S., and Mehran, K. M. 2009. "Integrating Multi-criteria Decision Analysis for a GIS-Based Hazardous Waste Landfill Sitting in Kurdistan Province, Western Iran." Waste Management 29 (10): 2740-58.

[29] Demesouka, O., Vavatsikos, A., and Anagnostopoulos, K. 2013. "Suitability Analysis for Siting MSW Landfills and Its Multicriteria Spatial Decision Support System: Method, Implementation and Case Study." Waste Management 33 (5): 1190-206.

[30] El Alfy, Z., Elhadary, R., and Ahmed, E. A. 2010. "Integrating GIS and MCDM to Deal with Landfill Site Selection." International Journal of Engineering \& Technology 10 (6): 32-42.

[31] Şener, B., Suzen, L. M., and Doyuran, V. 2006. "Landfill Site Selection by Using Geographic Information Systems." Environmental Geology 49 (3): 376-88.

[32] Wang, G., Qin, L., Li, G., and Chen, L. 2009. "Landfill Site Selection Using Spatial Information Technologies and AHP: A Case Study in Beijing, China." Journal of Environmental Management 90 (8): 2414-21.

[33] Sener, B. 2004. "Landfill Site Selection by Using Geography Information System.” Master's dissertation, Middle East Technical University.

[34] Isalou, A., Zamani, V., Shahmoradi, B., and Alizadeh, H. 2013. "Landfill Site Selection Using Integrated Fuzzy Logic and Analytic Network Process (F-ANP)." Environmental Earth Science 68: 1745-55.

[35] Motlagh, Z. K., and Sayadi, M. H. 2015. "Siting MSW Landfills Using MCE Methodology in GIS Environment (Case Study: Birjand Plain, Iran)." Waste Management 46: 322-37.

[36] Charnpratheep, K., Zhou, Q., and Garner, B. 1997. "Preliminary Landfill Site Screening Using Fuzzy Geographical Information Systems.” Waste Management 
\& Research 15 (2): 197-215.

[37] Gupta, R., Kewalramani, M. A., and Ralegaonkar, R. V. 2003. "Environmental Impact Analysis Using Fuzzy Relation for Landfill Siting." Journal of Urban Planning \& Development 129 (3): 121-39.

[38] Uyan, M. 2014. "MSW Landfill Site Selection by Combining AHP with GIS for Konya, Turkey." Earth Science 71 (4): 1629-39.

[39] Yildirim, V. 2012. "Application of Raster-Based GIS Techniques in the Siting of Landfills in Trabzon Province, Turkey: A Case Study." Waste Management \& Research 30 (9): 949-60.

[40] Sadek, S., El-Fadel, M., and Freiha, F. 2006. "Compliance Factors within a GIS-Based Framework for Landfill Siting." International Journal of Environmental Studies 63 (1): 71-86.

[41] Ouma, Y. O., Kipkorir, E. C., and Tateishi, R. 2011. "MCDA-GIS Integrated Approach for Optimized Landfill Site Selection for Growing Urban Regions: An Application of Neighborhood Proximity Analysis." Annals of GIS 17 (1): 43-62.

[42] Chabuk, A., Al-Ansari, N., Hussain, H. M., Knutsson, S., and Pusch, R. 2016. "Landfill Site Selection Using Geographic Information System (GIS) and AHP: A Case Study Al-Hillah Qadhaa, Babylon, Iraq." Waste Management \& Research 34 (5): 427-37.

[43] Iraqi Ministry of Water Resources. 1990. State Commission of Survey. Rusafa: Iraqi Ministry of Water Resources.

[44] Zeiss, C., and Lefsrud, L. 1995. "Analytical Framework for Waste-Facility Siting." Journal of Urban Planning and Development 121 (4): 115-45.

[45] Tagaris, E., Sotiropoulou, R. P., Pilinis, C., and Halvadakis, C. P. 2003. "A Methodology to Estimate Odors around Landfill Sites: The Use of Methane as an Odor Index and Its Utility in Landfill Siting." Journal of
Air \& Waste Management Association 53 (5): 629-34.

[46] Iraqi Ministry of Oil. 2015. Oil Pipelines Company: Limitations of Oil and Gas Pipelines Law No. 40145 in 1989.

[47] Rezaei-Moghaddam, K., and Karami, E. A. 2008. "A Multiple Criteria Evaluation of Sustainable Agricultural Development Models Using AHP.” Environment, Development and Sustainability 10 (4): 407-26.

[48] Saaty, T. L. 2008. "Decision Making with the Analytic Hierarchy Process." International Journal of Services Sciences 1 (1): 83-98.

[49] Hussain, M. H. 2004. "Assessment of Groundwater Vulnerability in an Alluvial Interfluve Using GIS.” Ph.D. thesis, Indian Institute of Technology Roorkee.

[50] Teknomo, K. 2006. "Analytic Hierarchy Process (AHP) Tutorial.” Revoledu.com. Accessed September 21, 2015. http://www.thecourse.us/5/library/AHP/AHP_Tutorial.pdf.

[51] Sólnes, J. 2003. "Environmental Quality Indexing of Large Industrial Development Alternatives Using AHP." Environmental Impact Assessment Review 23: 283-303.

[52] Chang, C., Wu, C., Lin, C., and Lin, H. 2007. "Evaluating Digital Video Recorder Systems Using Analytic Hierarchy and Analytic Network Processes." Information Sciences 177 (16): 3383-96.

[53] Coyle, G. 2004. "The Analytic Hierarchy Process (AHP)." Pearson Education Limited. Accessed December 30, 2015. http://www.booksites.net/download/coyle/student_files/A HP_Technique.pdf.

[54] Chabuk, A., Al-Ansari, N., Hussain, H. M., Knutsson, S., and Pusch, R. 2015. "Present Status of Solid Waste Management at Babylon Governorate, Iraq." Engineering 7: 408-23.

[55] Iraqi Ministry of Municipalities and Public Works. 2015. Records of Directorate of Babylon Municipalities, Babylon. Baghdad: Iraqi Ministry of Municipalities and Public Works. 